ROBERT MIRSKI ID orcid.org/0000-0002-1608-4734

Instytut Filozofii, Katolicki Uniwersytet Lubelski Jana Pawła II Faculty of Philosophy, John Paul II Catholic University of Lublin e-mail: robertmirski@kul.lublin.pl

\title{
Krytyka natywizmu jawnego i ukrytego w badaniach nad dziecięcymi teoriami umysłu
}

\author{
A Critique of Explicit and Implicit Nativism \\ in Research on Children's Theories of Mind
}

\begin{abstract}
The traditional theories of theory-of-mind development - modularist nativism, theory theory, and the two-systems theory - share a common model of mental representation. According to that model, the normative content of representation is encoded in its physical vehicle. In the present article, I point out that this claim entails the view that representation cannot emerge out of non-representational phenomena. This leads to the need of positing foundational mental content - foundationalism - and viewing cognitive development only as a reconfiguration of the innately given representations. As a result, all three models are forced to claim innate mental content, although only the modular nativists explicitly acknowledge it. Further, the idea that mental content is innate faces its own challenges: nativism does not seem to be a tenable position in either the "biological" or "psychological" sense of the term. I argue that nativism is a symptom of theoretical limitations, not a legitimate division of labor between psychology and other sciences.
\end{abstract}

Keywords: theory of mind, mindreading, mental representation, nativism, foundationalism, emergence

Słowa kluczowe: teoria umysłu, mindreading, natywizm, emergencja, reprezentacje mentalne, fundacjonizm

\section{WSTECP}

Stanowisko natywistyczne jest wciąż jednym $\mathrm{z}$ dominujących poglądów w psychologicznych badaniach nad rozwojem teorii umysłu (theory of mind, ToM) (e.g. Carruthers, 2013, 2015; Fodor, 1992; Helming, Strickland, Jacob, 2016; Leslie, Friedman, German, 2004; Onishi, Baillargeon, 2005; Scholl, Leslie, 2001; Scott, Baillargeon, 2017; Westra, 2017; Westra, Carruthers, 2017). Zwolennicy tego stanowiska zakładają, że centralnym mechanizmem poznawczym umożliwiającym poznanie społeczne jest wrodzony moduł czytania w umyśle; wrodzona teoria umysłu, która zawiera pojęcia przekonania i pragnienia dostępne już niemowlętom.

Natywizm wszelkiego rodzaju jest zazwyczaj obiektem krytyki, która stara się wykazać, że doświadczenie jest niezbędne do nabycia pojęć uznawanych za wrodzone lub że wystarcza ono do ich formacji. W badaniach nad poznaniem społecznym są to głównie argumenty powołujące się na wyniki empiryczne, które, jak argumentują przeciwnicy postulatu wrodzoności, są albo niespójne z perspektywą natywizmu, albo niewystarczające, żeby wykluczyć alternatywne interpretacje (Apperly, 2012; Apperly, Butterfill, 2009; Gopnik, 2003; e.g. Gopnik, 
Wellman, 1992; Perner, Ruffman, 2005; Ruffman, Taumoepeau, 2014). W niniejszym tekście przyjmę nieco inną perspektywę: pokażę, że natywizm jest również koniecznym stanowiskiem tych bardziej ,empirycystycznych” teorii (teorii teorii, teorii dwóch systemów) z powodów czysto teoretycznych - model reprezentacji, zakładanych przez tradycyjne podejścia ToM, wymusza postulat początkowych reprezentacji, z których rozwój poznawczy się rozpoczyna. W rezultacie te stanowiska, pomimo tego, że unikają „natywistycznej” nomenklatury, są również zmuszone do przyjęcia wrodzoności dla postulowanych fundamentów rozwojowych.

Następnie omawiam problem samego postulatu wrodzoności reprezentacji mentalnych: co miałby on oznaczać i czy jest do utrzymania. Rozważam dwa główne znaczenia ,wrodzoności" - zapożyczenie tego pojęcia z biologii oraz rozumienie go jako metodologicznej granicy psychologii. Pokazuję, że oprócz ograniczeń teoretycznych wymuszających ten pogląd nie ma powodów, aby z góry zakładać, że wyłonienie się pierwszych reprezentacji mentalnych leży poza obszarem psychologii.

\section{EMPIRYCZNE TLO}

Obecne wyniki badań empirycznych nad poznaniem społecznym można podzielić na trzy kategorie. Przedstawiam je poniżej w celu nakreślenia tła dla następujących po nich rozważań teoretycznych.

(1) Dzieci rozwiązują test fałszywych przekonań w paradygmacie spontanicznej reakcji dużo wcześniej niż tradycyjny test fałszywych przekonań (false-belief task, FBT), który wymaga odpowiedzi dziecka na pytanie testowe ${ }^{1}$. Ten pierwszy potrafią rozwiązać już piętnastomiesięczne dzieci, natomiast $\mathrm{z}$ tradycyjną wersją zaczynają sobie radzić dopiero czterolatki i starsze dzieci (Kovács, Téglás, Endress, 2010; Onishi, Baillargeon, 2005; Poulin-Dubois, Chow, 2009; Scott, Baillargeon, 2009; Scott, Baillargeon, Song, Leslie, 2010; Träuble, Marinović, Pauen, 2010).

(2) Czynniki językowe oraz społeczne w kontekście rozwoju dziecka wpływają na rozwój poznania społecznego, w tym na wiek, w którym dzieci zdają tradycyjny FBT (e.g. Kristen, Sodian, 2014; Milligan, Astington, La Dack, 2007; Nelson, 2005; Ruffman, Slade, Rowlandson, Rumsey, Garnham, 2003; de Villiers, de Villiers, 2014).

(3) Istnieją kultury, w których tłumaczy się zachowanie innych ludzi na sposoby radykalnie odmienne od zachodniej psychologii potocznej opartej na pojęciach umysłu i stanów mentalnych. Ponadto dzieci z tych kultur zazwyczaj rozwiązują testy poznania społecznego w innym wieku niż dzieci pochodzące z kultur Zachodu (e.g. Dixson, Komugabe-Dixson, Dixson, Low, 2017; Mayer, Träuble, 2012; Mills, 2001; Strijbos, De Bruin, 2013; Vinden, 1996; Wellman, Fang, Liu, Zhu, Liu, 2006; Wellman, Fang, Peterson, 2011).

Punkty 2 i 3 sugerują, że zdolność do rozumienia innych umysłów jest w znaczącym stopniu modulowana przez czynniki środowiskowe, takie jak kultura, język czy kontekst rodzinny. Wyniki wspomniane w punkcie 1 sugerują jednak istnienie jakiejś zdolności pozwalającej na przynajmniej minimalną kompetencję społeczną już w wieku 15 miesięcy. Empirycystyczno-natywistyczne „wahadło” kontynuuje swój nieustający ruch również na tle tych wyników (Allen, Bickhard, 2013): modularni natywiści postulują, że wyniki z punktu 1 są dowodem istnienia wrodzonego modułu czytania w umyśle opartego na pojęciach przekonania i pragnienia, podczas gdy zwolennicy poglądów bardziej empirycystycznych argumentują, że wcale tak być nie musi - dużo prostszy mechanizm może wyjaśnić te wyniki, a teoria umysłu oparta na zrozumieniu przekonań i pragnień jest wynikiem doświadczenia w środowisku, co współgra z wynikami wspomnianymi w punktach 2 i 3 .

Poniżej zwracam uwagę, że oba te stanowiska, pomimo różnic, które je dzielą, są przedmiotem tych samych teoretycznych ograniczeń. Zwracam uwagę na fakt, że natywizm jest poglądem wymuszonym przez tradycyjny pogląd na reprezentację mentalną. Pogląd ten jest wspólny zarówno stanowiskom jawnie natywistycznym, jak i tym, które unikają tego terminu. Zgodnie z prezentowanym tutaj argumentem stanowiska, które trwają przy korespondencyjnym modelu reprezentacji, są zmuszone ze względów teo- 
retycznych do przyjęcia postulatu pierwotnych reprezentacji. Różnica pomiędzy stanowiskami natywistycznymi i tymi, które się za takie nie uważają (lecz wciąż używają korespondencyjnej reprezentacji), jest jedynie taka, że te drugie przemilczają problem genezy pierwszych reprezentacji. Przedstawiony argument czerpie z krytyki prowadzonej przez Marka Bickharda od kilkudziesięciu lat, gdzie można dostrzec szerszą skalę tego problemu niż jedynie dyskutowane tutaj badania nad ToM (Allen, Bickhard, 2013; Bickhard, 2001, 2015, 2016; Bickhard, Richie, 1983; Bickhard, Terveen, 1995; Campbell, Bickhard, 1986).

\section{NATYWIZM - POGLĄD BARDZIEJ POWSZECHNY NIŻ SIE WYDAJE}

Tradycyjne stanowiska ToM (teoria teorii, modularny natywizm oraz niedawno zaproponowana teoria dwóch systemów) pracują z zasadniczo tym samym modelem reprezentacji mentalnej: treść semantyczna-czyli normatywność reprezentacji, to, co sprawia, że może być ona prawdziwa lub nie - jest rozumiana jako wynikająca $\mathrm{z}$ korespondencji z tym, co jest reprezentowane. Reprezentacja ,koduje” informację na temat desygnatu, stąd ten ogólny pogląd Bickhard określa mianem enkodyzmu (encodingism). Pogląd ten jest standardowy nie tylko w badaniach nad teorią umysłu, lecz także w ,podręcznikowej” psychologii poznawczej (zob. Nęcka, Orzechowski, Szymura, 2006). Fakt ten, niezależnie od bardziej szczegółowych różnic poszczególnych teorii, narzuca wspólne tym podejściom ograniczenia teoretyczne, które prowadzą do jawnego lub niejawnego natywizmu reprezentacji.

Korespondencyjny lub „enkodystyczny” model reprezentacji ma swoje korzenie w klasycznej teorii umysłu obliczeniowego, który ujmował poznanie za pomocą metafory komputera. Energia płynąca ze środowiska ma być przetworzona (transduced) na format układu nerwowego. Podstawowym założeniem i centralnym problemem - jest tutaj to, że owo przetworzenie ma skutkować powstaniem normatywnej treści mówiącej coś o środowisku. W klasycznych natywistycznych podejściach ta normatywność zawierała się w pojęciach, swoistym ,języku myśli” (Fodor, 1975), natomiast $\mathrm{w}$ podejściach bardziej empirycystycznych miała być ona zawarta w dużo prostszych reprezentacjach sensorycznych. Jednak w obu przypadkach konieczny jest postulat, że to, co czysto przyczynowe - energia docierająca do systemu poznawczego - zostaje przemianowane na to, co normatywne, co przynajmniej w minimalnym stopniu ,orzeka” coś o rzeczywistości. Jest to konieczne, ponieważ na tym właśnie polega poznanie - na zdobywaniu prawdziwej informacji o rzeczywistości i wykorzystywaniu jej w adaptacyjnych zachowaniach.

Na przykład sama energia elektromagnetyczna światła nie mówi nic o otaczającej rzeczywistości - system poznawczy musi już ,wiedzieć”, że pewne zmienności w świetle odnoszą się do przedmiotów czy bardziej ogólnych warunków mających miejsce w rzeczywistości. Tylko wtedy możemy otrzymać normatywną treść, na podstawie której system może podjąć jakieś działanie i spodziewać się sukcesu.

Staje się więc jasne, że sama korespondencja, na której ma zasadzać się treść semantyczna, nie jest wystarczającym warunkiem jej istnienia. Reakcja układu wzrokowego koresponduje zarówno z geometrią otoczenia, jak i samym światłem oraz także $\mathrm{z}$ molekularną strukturą przedmiotów i początkami wszechświata - postulat, że jeden zakres z tej korespondencji jest tym, o czym reprezentacja orzeka, jest czysto arbitralny. Sam fakt istnienia informacji nie wyjaśnia, w jaki sposób system o niej wie.

Centralny problem polega na tym, że pomimo długoletnich starań w ramach korespondencyjnego modelu reprezentacji nie udało się nikomu wyjaśnić, w jaki sposób to, co czysto przyczynowe, staje się normatywne, kiedy dociera do umysłu. W konsekwencji psychologia poznawcza poprzestała na założeniu, że treść reprezentacji jest już obecna w umyśle: bodźce ze środowiska aktywują schematy normatywne już w nim zawarte. Najbardziej wyczerpującą analizę tego problemu zaoferował Jerry A. Fodor, który podążając logicznymi konsekwencjami przyjętego modelu reprezentacji, został zmuszony do postulatu wrodzoności praktycznie wszystkich mentalnych reprezentacji, co wbrew 
temu, co się często o nim orzeka, nie było stanowiskiem, które uważał za właściwe:

(...) ten argument nie może być poprawny, (...) natywizm, który w rezultacie otrzymujemy, jest nie do utrzymania, (... ) coś bardzo ważnego musiało nam umknąć. Wydaje mi się, że wykazane konsekwencje nie stanowią apriorycznego argumentu za natywizmem, a raczej wskazują na to, że musi istnieć jakiś model uczenia się, który jest tak radykalnie różny od tego, co do tej pory sobie wyobrażaliśmy, że sam nie jestem w stanie zasugerować, jak mógłby on wyglądać (wypowiedź Fodora w Piattelli-Palmarini, 1980, s. 269)².

Problem wrodzoności reprezentacji nie jest nigdzie indziej tak problematyczny jak w poznawczej psychologii rozwojowej-zakładając, że to, co mentalne, już istnieje, przyznajemy w gruncie rzeczy, że nie jesteśmy w stanie odpowiedzieć na podstawowe pytanie tej nauki - skąd bierze się umysł. Presuponujemy to, co powinno być wyjaśnione. W kontekście badań rozwojowych problem ten został określony mianem fundacjonizmu (foundationalism) (Allen, Bickhard, 2013; Bickhard, Terveen, 1995) - przyjęty model reprezentacji jako korespondencji wymusza założenie istnienia początkowych reprezentacji, ponieważ jest logicznie niemożliwe wyprowadzenie normatywności z przyczynowości.

Kiedy już przyjmiemy, że normatywność istnieje $\mathrm{w}$ postaci wrodzonych reprezentacji, to modelowanie rozwoju poznawczego staje się relatywnie bezproblematyczne. Treść fundacyjnych reprezentacji jest łączona na wiele sposobów czysto mechanistycznie, co prowadzi do utworzenia złożonych pojęć i pozornego rozwoju poznawczego. Trzeba jednak zauważyć, że nie rozwiązaliśmy tutaj podstawowego problemu; nie powstaje w ten sposób zasadniczo nowa treść, a jedynie „opracowywane” są proste reprezentacje.

\section{FUNDACJONIZM W TEORIACH TOM}

W rezultacie powyższych ograniczeń teoretycznych każdy model, który przyjmuje, że reprezentacja „koduje” swoją treść, musi założyć istnienie podstawowych reprezentacji, czy to w postaci pojęć, czy ,,prostszych” struktur normatywnych. Problem ten jest widoczny w podejściach ToM, zarówno tych „,natywistycznych”, jak i tych, które unikają tego terminu.

Modularny natywizm ToM otwarcie przyjmuje konsekwencje swojego modelu poprzez postulat, że pierwsze reprezentacje są wrodzone. Podobnie jak w przypadku modularnych modeli innych zdolności poznawczych (Lightfoot, 1989; Pinker, 2014/1994; Wynn, 1992), mechanizm czytania w umyśle ma wyglądać następująco: istnieje genetycznie determinowany mechanizm lub modut, który jest przeznaczony do konkretnej dziedziny poznawczej - w naszym wypadku czytania w umyśle. Mechanizm ten jest niezależny od reszty systemu poznawczego i niewrażliwy na jakiekolwiek pozasystemowe czynniki rozwojowe. Rozwija się według genetycznie (lub ,biologicznie”) predeterminowanego grafiku (timetable). Informacja, która jest wrodzona w jego postaci, zawiera podstawowe pojęcia (przekonanie, pragnienie, widzenie czy udawanie) oraz heurystyki (np. ,jeśli ktoś coś zobaczy, to tworzy na ten temat przekonanie"), co umożliwia dziecku selekcję relewantnej informacji sensorycznej, przetłumaczenie jej na format kodu modułu oraz wyciągnięcie podświadomych wniosków. Wnioski te są następnie inkorporowane w centralny system, co dodaje aspekt psychiki drugiego człowieka w postrzeganej rzeczywistości. Jak twierdzą Evan Westra i Peter Carruthers (2017), wrodzony moduł czytania w umyśle może być wzbogacony: albo w jakiś sposób jego wyjściowy zestaw pojęć się rozszerza (Westra, Carruthers, 2017), albo harmonizacja z resztą systemu poprawia się, co umożliwia bardziej złożone wnioskowania wynikające ze współpracy modułu z innymi modułami/systemem centralnym (Carruthers, 2015; Fodor, 1992; Leslie, Friedman, German, 2004).

Zwolennicy natywizmu tłumaczą różnice rozwojowe z punktów 2 i 3 przedstawionych na początku tekstu oraz wpływ czynników środowiskowych w nich wspomniany, przytaczając inne problemy niż brak samego zrozumienia umysłu przez dziecko. Twierdzą, że dany test albo wymaga pojęć bardziej złożonych niż moduł czytania w umyśle dostarcza (np. zazdrości), albo 
trudności dziecka tłumaczą się klasycznym już rozbratem pomiędzy kompetencją a czynnikami wykonawczymi (competence-performance). To ta druga ścieżka jest konieczna przy interpretacji wyników FBT i podobnych testów: testy te badają zdolności, które natywiści uznają za wrodzone (jak zrozumienie fałszywych przekonań), a dzieci wciąż rozwiązują je w stopniu zależnym od kontekstu rozwoju.

Zwolennicy natywizmu postulują, że dziecko rozumie fałszywe przekonania od urodzenia, a różnice $\mathrm{w}$ rozwiązywaniu przez nie testów ToM skorelowane z czynnikami środowiskowymi mają swe źródło w (a) niezrozumieniu implikatur pytań testowych, (b) braku odpowiedniego słownictwa w języku, w którym dziecko dorasta, lub (c) nierozwiniętych jeszcze dostatecznie funkcjach wykonawczych albo ogólnych procesach obliczeniowych (Fodor, 1992; cf. Helming i in., 2016; Westra, Carruthers, 2017). Innymi słowy, czynniki środowiskowe wpływają na rozwój zdolności komunikacyjnych dziecka i funkcji wykonawczych, nie na rozwój jego modułu czytania w umyśle. To te pierwsze stoją na drodze ekspresji zrozumienia innych umysłów przez początkowe lata życia dziecka, osiągając wystarczające stadium rozwoju w różnym czasie, w zależności od kontekstu rozwojowego.

Natywiści mówią otwarcie o wrodzonych pojęciach. Jednak również stanowisko racjonalnego konstruktywizmu (teoria teorii), które jest głównym przeciwnikiem modularnego natywizmu, pada ofiara fundacjonizmu i jest zmuszone do przynajmniej implicytnego zakładania wrodzoności (Gopnik, 2009, 2010, 2011; Gopnik, Meltzoff, Kuhl, 1999; Gopnik, Wellman, 1992, 2012; Wellman, 2014). Teoria teorii zakłada, że rozwój poznawczy zachodzi analogicznie do rozwoju teorii w nauce, i jej zwolennicy posługują się metaforą „małego naukowca", którym ma być dziecko. Ma zacząć ono swój rozwój poznawczy z zestawem pojęć służących mu do stawiania hipotez, które potem kontrastuje z rzeczywistością poprzez przeprowadzanie ,eksperymentów”. Proces ten jest czysto formalny i jest wsparty teorią wnioskowań Bayesowskich (Gopnik, Bonawitz, 2015; Gopnik, Tenenbaum, 2007). Nie wyjaśnia to jednak, skąd reprezentacje uży- wane w tym procesie zdobywają swoją treść, i w rezultacie mamy do czynienia z kolejnym przykładem fundacjonizmu. Fakt ten widać klarownie $\mathrm{w}$ poniższym fragmencie $\mathrm{z}$ książki Henry'ego M. Wellmana:

Każdy model rozwoju musi ustalić zarówno stany początkowe organizmu, jak i mechanizmy rozwoju - początki oraz rozwój. Nie sposób obyć się bez tych dwóch elementów, aczkolwiek oczywiście można postulować bogatsze lub mniej zasobne stany początkowe oraz bardziej złożony lub prostszy rozwój. Każdy model, taki jak teoria teorii, który podkreśla rolę uczenia się w rozwoju, musi zawierać stany początkowe oraz mechanizmy uczenia się, które przekształcają stany początkowe w późniejsze struktury (Wellman, 2014, s. 197).

Rozwój rozumiany jako rozwój teorii musi zacząć się od postulatu istniejących już pojęć pierwszej minimalnej teorii. Żeby w ogóle się rozpoczął, musi zostać postawiona pierwsza hipoteza, a żeby to nastąpiło, musi już istnieć teoria i jej pojęcia. W konsekwencji, pomimo że Alison Gopnik, Wellman i ich współpracownicy unikają pojęcia wrodzoności, wydaje się, że nie mają innego wyjścia, jak również uciec się do natywizmu. W każdym razie teoria teorii nie jest odpowiednim modelem rozwoju poznawczego, ponieważ presuponuje to, co taki model wyjaśnić powinien - emergencję normatywności.

Nowszym wariantem podejść ToM jest teoria dwóch systemów (Apperly, 2012; Apperly, Butterfill, 2009; Butterfill, Apperly, 2013; Low, Apperly, Butterfill, Rakoczy, 2016). Zakłada się tutaj, że ludzie są w posiadaniu dwóch systemów, którymi posługują się w nawigacji życia społecznego. System 1 jest prostym mechanizmem, który umożliwia ,śledzenie” stanów mentalnych innych ludzi, ale nie reprezentuje ich w sposób refleksyjny (czyli jako stanów mentalnych). System 2 jest świadomym mechanizmem refleksji nad życiem mentalnym drugiego człowieka.

Motywacja do postulatu dwóch systemów czytania w umyśle była empiryczna: przepaść pomiędzy 15-miesięcznymi dziećmi zdającymi test fałszywych przekonań w paradygmacie 
spontanicznej reakcji a dopiero 4-latkami zdającymi eksplicytny test fałszywych przekonań jest tutaj wyjaśniona poprzez funkcjonowanie dwóch systemów poznawczych, z czego drugi rozwija się później. Ian A. Apperly i Stephen A. Butterfill przeprowadzili wiele dalszych badań, które pokazują, że nawet u dorosłych oba te systemy działają niezależnie (Apperly, 2012).

W kontekście problemu fundacjonizmu teoria dwóch systemów nadal napotyka te same aporie, ponieważ jej autorzy również presuponują korespondencyjną teorię reprezentacji. Apperly i Butterfill są dużo ostrożniejsi w swoich teoretycznych postulatach niż zwolennicy dwóch poprzednich podejść, jednak wciąż nawet ich system 1 rozpoczyna swoje istnienie $\mathrm{z}$ zestawem reprezentacji:

Nie mamy na celu argumentowanie, że osoba może śledzić przekonania, prawdziwe i fałszywe, bez jakiegokolwiek poznania opartego na teorii umysłu. Chcemy raczej zaproponować minimalną formę poznania opartego na teorii umysłu. (...) minimalna teoria umysłu reprezentuje stany mentalne podobne do przekonań, ale nie reprezentuje przekonań oraz innych postaw propozycjonalnych jako takich (Butterfill, Apperly, 2013, s. 3).

Teoria dwóch systemów wciąż skupia się na problemie askrypcji stanów mentalnych obserwowanym podmiotom. W konsekwencji system 1 , pomimo swojej minimalistycznej struktury, wciąż presuponuje, że dziecko jest w stanie reprezentować podmioty i przedmioty oraz że podmioty rejestrują przedmioty. Czyli znowu mamy do czynienia z założeniem normatywności poznania bez jej wyjaśnienia. Autorzy dwóch systemów, podobnie jak teoretycy teorii, unikają twierdzeń na temat wrodzoności, lecz nie sposób nie odnieść wrażenia, że i oni nie mają innego wyjścia.

Przedstawione teorie ToM padają ofiarą fundacjonizmu ze względu na model reprezentacji, który zakładają. W tym kontekście ich główną różnicą jest to, jak złożone reprezentacje są początkiem rozwoju (np. dla Wellmana jest to pojęcie pragnienia i świadomości (awareness), dla modularystów pojęcia przekonania i pragnienia) - jednak w każdym z trzech przypadków rozwój normatywności jako takiej pozostaje niewyjaśniony.

\section{PROBLEMY Z POJECIEM WRODZONOŚCI}

$Z$ racji tego, że wrodzoność pierwszych reprezentacji jest jawnym (natywizm) i potencjalnym (teoria teorii, teoria dwóch systemów) wyjściem $\mathrm{z}$ fundacjonizmu, poniżej rozważam, czy sam postulat wrodzoności ma sens.

\section{Wrodzoność z perspektywy biologii}

Timothy P. Racine (2013) zauważa, że podejścia zakładające wrodzoną wiedzę zazwyczaj wykorzystują neodarwinowski pogląd na wrodzoność, że wrodzone pojęcia były obiektem presji selekcyjnych w filogenezie ze względu na ich adaptacyjność i stąd są one zakodowane $w$ genach i przez to koniecznie rozwijają się w ontogenezie (zob. np. Carruthers, 2013, s. 151). Problem fundacjonizmu nie jest więc rozwiązany, a jedynie zrzucony na biologię. Biologia jednak podważa tak prostolinijne stanowisko; staje się jasne, że złożone cechy fenotypiczne, takie jak pojęcia, są wynikiem interakcji czynników rozwojowych, która wymaga wyjaśnienia, a nie przyjęcia za pewnik.

W biologii panuje obecnie atmosfera wielkich zmian, a niektórzy okrzyknęli już wiek XXI wiekiem biologii (Venter, Cohen, 2004). Jednym z głównych problemów w tym rewolucyjnym klimacie jest pojęcie wrodzoności. Pod wpływem prac takich naukowców jak Richard Ch. Lewontin czy Stephen J. Gould współczesna biologia dużo ostrożniej postuluje adaptacjonistyczne wyjaśnienia rozwoju cech fenotypicznych; pogląd, że są wrodzone i konieczne w ontogenezie (Gould, Lewontin, 1979; Lewontin, 2001; Oyama, 1985/2000).

Badania z zakresu biologii pokazują, że rozwój osobniczy jest determinowany wieloma czynnikami i zachodzącymi pomiędzy nimi relacjami (multiply contigent) (Elman, 1996; Gould, Lewontin, 1979; Gould, Vrba, 1982; Mameli, Bateson, 2011; Oyama, 1985/2000; Pigliucci, Müller, 2010). Wielu psychologów, szczególnie rozwojowych, ponagla, że musi być to uwzględnione $\mathrm{w}$ badaniach nad rozwojem poznawczym (Carpendale, Hammond, Atwood, 2013, s. 130; Carpendale, Wereha, 2013, s. 208; 
Lewis, Carpendale, Stack, 2013, s. 159-160; Lewkowicz, 2011; Spencer i in., 2009). Zwracają oni uwagę na to, że istnieje wiele elementów, których interakcja prowadzi do wyłonienia się form poznawczych, i stąd jakakolwiek rozmowa o ,wrodzoności”, czyli o zakodowaniu w genach czy jakiekolwiek innej ,„preegzystencji”, wypacza rzeczywisty sposób, w jaki geny lub inne interaktanty rozwojowe mają znaczenie w ontogenezie. „Interakcjonistyczna lekcja”, którą się wynosi ze współczesnej biologii, jest taka, że geny mają dane znaczenie dla ontogenezy tylko i wyłącznie w kontekście innych, zarówno wewnątrz-, jak i zewnątrzorganizmowych czynników/interaktantów. Innymi słowy, mają one swoją ,informację” o konkretnej cesze tylko wtedy, kiedy inne przyczyny występują. Ta interakcyjna natura zjawisk ontogenetycznych sprawia, że nie ma zbyt wielkiego sensu mówić o wrodzoności jako o cechach ,zapisanych w genach". Można by równie dobrze powiedzieć, że wrodzone cechy są ,zapisane w środowisku”, jako że moc przyczynowa genów jest możliwa dzięki konkretnemu zakresowi środowisk: „Geny są niezbędnym czynnikiem w systemie wzajemnie oddziałujących na siebie czynników; złożoność wyłania się, a nie preegzystuje na jakimkolwiek wcześniejszym etapie rozwoju" (Carpendale, Wereha, 2013, s. 208).

Natywistyczny pogląd na rozwój poznania społecznego ignoruje powyższy postęp w zrozumieniu rozwoju poznawczego i używa pojęcia wrodzoności, które nie jest spójne ze współczesną biologią. Spójrzmy na poniższy cytat z Petera Carruthersa (2013):

Hipoteza wczesnego czytania w umyśle postuluje wrodzoną wiedzę podstawową lub wrodzenie ustrukturalizowany mechanizm obliczeniowy (albo obydwa powyższe), które przypominają prostą teorię umysłu. Ciężar wyjaśnień pada więc na procesy ewolucyjne: trzeba wykazać, że zaszły wystarczające presje adaptacyjne w życiu naszych przodków, aby mechanizm czytania w umyśle wyewoluował. Istnieje już pokaźna grupa badań, które sugerują, że właśnie tak było. Zysk, jaki organizm czerpie z takiego mechanizmu, bierze się stąd, że umożliwia on tak zwaną inteligencję machiavelistyczną (Byrne and
Whiten, 1988, 1997) czy typowo ludzkie formy kooperacji i kolaboracji (Richerson and Boyd, 2005; Hrdy, 2009), czy jakąkolwiek kombinację powyższych (Carruthers, 2013, s. 151).

Według Carruthersa głównym wyzwaniem natywizmu jest przedstawienie adaptacyjnych argumentów z filogenezy, które domniemanie mają wyjaśniać ontogenetyczny rozwój danej cechy. W rzeczywistości adaptacyjne wyjaśnienia nie są mocnymi wyjaśnieniami rozwoju osobniczego; filogenetyczne adaptacje nie $s a$ preformowanymi fenotypami, które każdy osobnik danego gatunku koniecznie wykształca w ontogenezie. Mowa o „wrodzonych cechach” ma miejsce w analizach filogenetycznych, gdzie termin oznacza ,zazwyczaj obecny w osobnikach danego gatunku w danym środowisku"; analizach, gdzie przyjmuje się, że środowiskowe kontyngencje są niezmienne, i skupia się uwagę na zmianach $w$ fenotypie na przestrzeni czasu filogenetycznego. Kiedy jednak jesteśmy zainteresowani ontogenezą, staramy się wyjaśnić dokładnie to, co neodarwinizm uogólnia - kontyngencje rozwoju, i to, jak spuścizna filogenetyczna wchodzi w interakcję $\mathrm{z}$ konkretnym kontekstem rozwojowym. Fakt, że dana cecha wyewoluowała przez adaptację w filogenezie, nie mówi nam praktycznie nic o tym, w jaki sposób wyłania się ona w ontogenezie (Oyama, 1985/2000, s. 25).

W tym kontekście trzeba pamiętać, że selekcja genetyczna zachodzi w środowisku i konkretne elementy tego środowiska są niezbędne, żeby wyselekcjonowane geny wykształciły w ontogenezie cechę, przez którą zostały wyselekcjonowane. To, co jest więc ,wrodzone”, to nie genetyczne zakodowanie, które jest problemem biologa, a raczej stabilność pomiędzy organizmem i środowiskiem, którą każdy model rozwoju musi opisać i wyjaśnić.

\section{Wrodzoność jako psychologiczne podstawy}

W minimalnym sensie fundacjonizm prowadzi do stanowiska, w którym badacz stwierdza, że reprezentacje stanowiące początek rozwoju nie są jego dziedziną - wyjaśnienie ich emergencji ma leżeć poza obszarem jego zainteresowania. Richard Samuels (2002, 2004), po przeglądzie 
dostępnych znaczeń pojęcia wrodzoności, dochodzi do podobnego wniosku, że w najbardziej obiecującym znaczeniu wrodzoności w psychologii i kognitywistyce nie używa się pojęcia wrodzoności zapożyczonego z biologii (gdzie, jak pokazaliśmy, ono tak naprawdę nie funkcjonuje w obecnych czasach), ale raczej ma specyficzne dla tych nauk znaczenie. Według tego poglądu wrodzone struktury poznawcze to takie, których psychologia nie może wyjaśnić. Jej wyjaśnienie miałoby spaść na inną, ,niższą" naukę i jak sam Samuels sugeruje (i wydaje się, że wyjścia tutaj innego za bardzo nie ma) tą nauką ma być biologia.

Stwierdzenie jednak, że psycholog zajmujący się rozwojem poznawczym miałby postrzegać problem rozwoju pierwszych pojęć jako „nie swoją działkę", wydaje się co najmniej zaskakujące. Analogicznie, trudno znaleźć biologa, który by twierdził, że problem początków życia jest domeną wyłącznie „niższych” nauk, a biologia nie ma w tej kwestii nic do powiedzenia. W obliczu powyższych rozważań można jednak zrozumieć, dlaczego tak trudno zrezygnować z pojęcia wrodzoności w naukach o umyśle - dominująca w nich teoria wymusza takie stanowisko i nie ma po prostu innego wyjścia. Można jedynie przemilczeć genezę pierwszych reprezentacji, co w gruncie rzeczy nie stanowi żadnej alternatywy.

Jak Samuels zauważa, powyższe rozumienie wrodzoności zakłada, że istnieje jasno wyznaczona granica pomiędzy przedmiotem biologii i psychologii. Choć naukowcy zakładają, że taka granica istnieje, to jednak nie jest to oczywiste, zwłaszcza kiedy bierzemy pod uwagę obszar poznawczej psychologii rozwojowej - dziedziny „na styku” tych dwóch obszarów. Co więcej, coraz częściej pojawiają się głosy, że nie można kreślić takiej granicy i że poznanie jest inherentnym aspektem życia (Di Paolo, Cuffari, Jaegher, 2018; Kirchhoff, Froese, 2017). Jednak stanowiska, które tak twierdzą, to takie, które porzuciły model reprezentacji jako korespondencji - czyli takie, które pozbyły się teoretycznych ograniczeń płynących z tego paradygmatu, co pozwoliło im na eksplorację procesów powodujących wyłanianie się psychiki.

Jak już zostało omówione przy okazji wrodzoności w biologii, rozwój osobniczy, czy to biologiczny, czy psychologiczny, jest procesem interakcji wielu czynników, zarówno wewnętrznych, jak i zewnętrznych wobec organizmu. Postulat wrodzoności nie jako zakodowania w genach, a jedynie przedmiotowej zewnętrzności z perspektywy psychologii niewiele tutaj zmienia - wydaje się, że nie ma powodów, żeby z góry zakładać, że wyłonienie się normatywności pierwszych reprezentacji zachodzi poprzez interakcję czynników, którymi zajmuja się biologia, chemia lub fizyka, a nie psychologia.

Sama biologia rozwojowa wydaje się podzielać taki pogląd. Armin P. Moczek (2014) np. definiuje rozwój w kontekście biologii rozwojowej jako ,sumę wszystkich procesów i wchodzących w interakcję komponentów, które są wymagane, aby forma organizmu i jego funkcja, na wszystkich poziomach organizacji biologicznej, zaczęły istnieć” (s. 218). Zauważmy, że opierając się tej definicji, mamy dwa wyjścia: albo trzymamy się przedstawionego tutaj postulatu, że rozwój w biologii dotyczy jedynie „wszystkich poziomów organizacji biologicznej”, albo rozszerzymy tę definicję o poziomy organizacji psychologicznej. Jeśli wybierzemy to pierwsze, to automatycznie wykluczamy możliwość, żeby biologia odpowiedziała na proces rozwoju pierwszych reprezentacji - reprezentacje mentalne stanowią element organizacji psychologicznej, nie biologicznej, i stąd ta definicja ich nie obejmie - wyjaśnienie emergencji reprezentacji mentalnych stanie się wtedy obszarem niczyim, odrzucanym zarówno przez psychologię, jak i biologię.

Jednak jeśli rozszerzymy tę definicję i uwzględnimy wyjaśnienie organizacji psychologicznej, nie będzie podstaw - oprócz ograniczeń teoretycznych fundacjonizmu - żeby zakładać, że $\mathrm{z}$ wchodzących $\mathrm{w}$ interakcje komponentów potrzebnych do wyłonienia się treści mentalnej żaden nie mógłby być studiowany przez psychologa. Scott F. Gilbert (2001; 2015) podkreśla rolę czynników środowiskowych w sumie tych procesów i zwraca uwagę, że rozwój układu nerwowego jest obszarem rozwoju w największym stopniu ze wszystkich aspektów rozwoju osobniczego zależnym od doświadczenia w środowisku. System nerwowy jest ogromnie plastyczny i otwarty na dia- 
metralne zmiany na początku życia człowieka i stąd biologicznie ,zaprogramowane” schematy aktywacji stanowiące pierwsze reprezentacje są tezą trudną do obrony (Elman, 1996). Mikromorfologia, włączając połączenia neuronalne, jest nastrojona na wpływ środowiska (Pezzulo, Vosgerau, Frith, Hamilton, Heyes, Iriki, Jörntell, König, Nagel, Oudeyer, Rupert, Tramacere, 2015), co ma również sens z adaptacyjnego punktu widzenia, gdyż umożliwia dziecku większą sprawność w nowym środowisku, nawet jeśli jest ono odmienne od środowiska przeszłych pokoleń. W rzeczy samej, jeśli tylko uznamy możliwość, że rozwój pierwszych zjawisk psychicznych zachodzi przy udziale doświadczenia, to nie sposób zaprzeczyć, że ten udział stanowi naturalny obszar badań w psychologii rozwojowej.

Wątpliwe zatem, czy niezbędna dla zjawisk psychicznych normatywność reprezentacji wyłania się tylko i wyłącznie poprzez interakcję czynników z obszarów, którymi zajmują się nauki „niższe” od psychologii. Sprawa oczywiście nie jest przesądzona i choć niepewna, taka możliwość istnieje. Wydaje się, że postulat wrodzoności pojęć nie jest wynikiem rzetelnego podziału obowiązków pomiędzy psychologię i inne nauki, a raczej koniecznym ruchem teoretycznym narzucanym przez ograniczenia inherentne modelowi klasycznej psychologii poznawczej - fundacjonizm.

W kontekście badań ToM jest możliwe, że już niemowlęce zdolności społeczno-poznawcze obserwowane w testach fałszywych przekonań paradygmatu spontanicznej reakcji rozwijają się właśnie w ten sposób, w koniecznym zintegrowaniu czynników środowiskowych doświadczenia dziecka - oraz czynników wewnętrznych, jego wrodzonej (i.e. ,biologicznie” rozwijanej) reaktywności organizmu. Wyniki otrzymane przez Marka Meristę, Karin Strid i Erland Hjelmquist (2016) potwierdzają tę hipotezę (zob. również Meristo i in., 2012). W badaniach tych niesłyszące dzieci nie rozwiązywały FBT spontanicznej reakcji, podczas gdy słyszące dzieci w tym samym wieku tak. Nasuwa się więc wniosek, że nawet ta wczesna kompetencja do rozwiązywania tej wersji FBT nie jest problemem biologa, lecz wyłania się poprzez interakcję dziecka ze środowiskiem, co psychologia rozwojowa może badać. Interpretacja zaproponowana przez Meristę i in. (2016) zwraca uwagę na konieczność interakcji dziecka w obrębie rodziny, aby rozwinęło ono tę podstawową kompetencję.

Wyniki nie są jednak jednoznaczne. Inni badacze (np. Barrett, Broesch,Scott, He, Baillargeon, Di Wu, Bolz, Henrich, Setoh, Wang, Laurence, 2013) przedstawiają dane świadczące o uniwersalności rozwiązywania FBT w paradygmacie spontanicznej reakcji. Oczywiście potrzeba więcej danych empirycznych, żeby wyciągać mocniejsze wnioski. Trzeba jednak pamiętać, że nawet jeśli wszystkie 15-miesięczne dzieci będą rozwiązywać FBT spontanicznej reakcji, to nie będzie to oznaczać prawdy natywizmu. Biorąc pod uwagę interakcyjną naturę zjawisk rozwojowych, będzie to raczej konsekwencją podobieństwa kontekstów rozwoju dla wszystkich dzieci w tym właśnie wieku. Samo stwierdzenie uniwersalności będzie wymagało dalszych badań, żeby ustalić, jak dokładnie zdolność rozwiązywania tego testu się rozwija i czym tak naprawdę jest. Trzeba będzie zbadać naturę poszczególnych kontekstów rozwojowych dzieci i starać się ustalić potencjalne czynniki, które grają rolę w ustalonym uniwersalizmie. Centralne będą tu badania obserwacyjne, skupiające się na pojedynczych dzieciach i sekwencjach ich rozwoju. Dopiero kiedy tego typu badania wykluczą jakąkolwiek rolę czynników środowiskowych w tym zadaniu, będziemy mogli postulować uznanie wrodzoności tej zdolności (i.e. jej emergencję wyjaśnianą całkowicie z perspektywy biologicznej).

\section{PODSUMOWANIE}

Klasyczne teorie rozwoju ToM - modularny natywizm, teoria teorii oraz teoria dwóch systemów - operują modelem reprezentacji mentalnej zakładającej, że treść semantyczna jest zakodowana w jej fizycznym nośniku. Ten teoretyczny postulat wymusza pogląd, że reprezentacje nie mogą powstać $z$ niereprezentacyjnych procesów, co prowadzi do konieczności postulowania początkowych reprezentacji stanowiących punkt 
wyjścia rozwoju - fundacjonizm - a sam rozwój jest stanowiony jedynie przez ,rekonfigurowanie" tych wrodzonych treści. W rezultacie wszystkie powyższe stanowiska są zmuszone do postulowania wrodzonych reprezentacji, choć tylko podejście modularno-natywistyczne mówi o tym otwarcie.

Jedno znaczenie wrodzoności to zapożyczone z biologii ,zakodowanie w genach”; pojęcie, które już od jakiegoś czasu w biologii nie funkcjonuje, ze względu na złożoną, wieloelementową naturę zjawisk rozwojowych, której geny są jedynie częścią, i nie jest wobec tego przydatne w psychologii. Drugie, częściej proponowane znaczenie pojęcia wrodzoności w psychologii i kognitywistyce to metodologiczny podział obowiązków - wrodzone ma być to, co wychodzi poza obszar badań psychologii. Jednakże wydaje się, że nie ma powodu, aby sądzić a priori, że proces emergencji pierwszych reprezentacji mentalnych (pierwszej normatywności) nie jest stanowiony po części przez procesy, które psychologia może badać. Staje się więc jasne, że głównym motywem uznania postulatu wrodzonych pojęć nie jest żadne z powyższych ustaleń teoretycznych czy metodologicznych, a jedynie ograniczenia przyjętych ram teoretycznych, które nie są w stanie modelować emergencji treści mentalnej ze zjawisk niereprezentacyjnych i są zmuszone do postulowania pierwotnych pojęć, mogących służyć jako źródło inherentnej psychice normatywności.

Obecne rozważania wskazują na potrzebę zmian w teoretycznych podstawach badań nad teorią umysłu. Trzeba wypracować model, który nie będzie wykluczał zjawiska emergencji treści mentalnej podczas ontogenezy a priori, i przy pomocy którego będzie można otrzymać pojęcie wrodzoności zgodne z naturą studiowanego przedmiotu - rozwoju ludzkiej psychiki. Podejścia modelujące rozwój poznawczy oparte na działaniu podmiotu (action-based, action-oriented) stanowią jedną z obiecujących alternatyw (Pezzulo i in. 2015; Allen, Bickhard, 2013), lecz dyskusja ich założeń leży poza zakresem niniejszego tekstu.

\section{PRZYPISY}

$1 \quad$ Test fałszywych przekonań ma na celu ustalenie, czy dziecko rozumie, że osoba posiadająca fałszywe przekonanie będzie zachowywać się według tego przekonania, a nie według znanej dziecku prawdzie (zob. Wimmer, Perner, 1983). Alternatywna wersja testu przeprowadzona w paradygmacie spontanicznej reakcji zastępuje eksplicytne pytanie pomiarem czasu skupienia wzroku podczas każdego z możliwych scenariuszy (zachowanie zgodne z fałszywym przekonaniem i zachowanie zgodne z rzeczywistością). Dłuższy czas skupienia wzroku interpretuje się jako efekt zaskoczenia dziecka, a co za tym idzie jego przeciwnych do obserwowanego scenariusza oczekiwań (zob. Onishi, Baillargeon, 2005).

$2 \quad$ Wszystkie tłumaczenia cytatów zostały dokonane przez autora tekstu.

\section{BIBLIOGRAFIA}

Allen J.W.P., Bickhard M.H. (2013), Stepping off the pendulum: Why only an action-based approach can transcend the nativist-empiricist debate. Cognitive Development, 28(2), 96-133. DOI: https://doi.org/10.1016/j. cogdev.2013.01.002.

Apperly I.A. (2012), Mindreaders: The Cognitive Basis of 'Theory of Mind'. Hove: Psychology.

Apperly I.A., Butterfill S.A. (2009), Do humans have two systems to track beliefs and belief-like states? Psychological Review, 116(4), 953-970. DOI: https://doi.org/10.1037/a0016923.

Barrett H.C., Broesch T., Scott R.M., He Z., Baillargeon R., Di Wu, Laurence S. (2013), Early false-belief understanding in traditional non-Western societies. Proceedings. Biological Sciences, 280(1755), 20122654. DOI: https://doi.org/10.1098/rspb.2012.2654.

Bickhard M.H. (2001), Why children don't have to solve the frame problems: cognitive representations are not encodings. Developmental Review, 21(2), 224-262. DOI: https://doi.org/10.1006/drev.2000.0521. 
Bickhard M.H. (2015), What could cognition be if not computation... Or connectionism, or dynamic systems? Journal of Theoretical and Philosophical Psychology, 35(1), 53-66. DOI: https://doi.org/10.1037/a0038059.

Bickhard M.H. (2016), Probabilities over what? Human Development, 59(1), 34-36. DOI: https://doi. org/10.1159/000447026.

Bickhard M.H., Richie D.M. (1983), On the Nature of Representation: A Case Study of James Gibson's Theory of Perception / Mark H. Bickhard, D. Michael Richie with Robert Hughes, James Dannemiller. New York, NY, USA: Praeger.

Bickhard M.H., Terveen L. (1995), Foundational Issues in Artificial Intelligence and Cognitive Science: Impasse and Solution. Advances in Psychology: nr. 109. Amsterdam, New York: Elsevier.

Butterfill S.A., Apperly I.A. (2013), How to construct a minimal theory of mind. Mind \& Language, 28(5), 606-637. DOI: https://doi.org/10.1111/mila.12036.

Campbell R.L., Bickhard M.H. (1986), Knowing Levels and Developmental Stages. Contributions to Human Development: $n r$. 16. Basel: S. Karger.

Carpendale J.I.M., Wereha T.J. (2013), understanding common developmental timetables across cultures from a developmental systems perspective. Human Development, 56(3), 207-212. DOI: https://doi. org/10.1159/000351276.

Carpendale J.I.M., Hammond S.I., Atwood S. (2013), A Relational developmental systems approach to moral development. W: R.M. Lerner, J.B. Benson (eds.), Advances in Child Development and Behavior. Embodiment and Epigenesis: Theoretical and Methodological Issues in Understanding the Role of Biology within the Relational Developmental System - Part B: Ontogenetic Dimensions, $\mathrm{nr} 45,125-153$. Elsevier. DOI: https://doi.org/10.1016/B978-0-12-397946-9.00006-3.

Carruthers P. (2013), Mindreading in infancy. Mind \& Language, 28(2), 141-172. DOI: https://doi.org/10.1111/ mila.12014.

Carruthers P. (2015), Mindreading in adults: Evaluating two-systems views. Synthese. Artykuł w czasopiśmie internetowym. DOI: https://doi.org/10.1007/s11229-015-0792-3.

Di Paolo E.A., Cuffari E.C., Jaegher, H. de (2018), Linguistic Bodies: The Continuity between Life and Language. Cambridge, MA: The MIT Press.

Dixson H.G.W., Komugabe-Dixson A.F., Dixson B.J., Low J. (2017), Scaling theory of mind in a small-scale society: a case study from Vanuatu. Child Development. Artykuł w czasopiśmie internetowym. DOI: https://doi.org/10.1111/cdev.12919.

Elman J.L. (ed.) (1996), Neural Network Modeling and Connectionism. Rethinking Innateness: A Connectionist Perspective on Development. Cambridge, MA: The MIT Press.

Fodor J.A. (1975), The Language of Thought. The Language and Thought Series. New York: Crowell.

Fodor J.A. (1992), A theory of the child's theory of mind. Cognition, 44(3), 283-296. DOI: https://doi. org/10.1016/0010-0277(92)90004-2.

Gilbert S.F. (2001), Ecological developmental biology: developmental biology meets the real world. Developmental Biology, 233(1), 1-12. DOI: https://doi.org/10.1006/dbio.2001.0210.

Gilbert S.F., Epel D. (2015), Ecological Developmental Biology: The Environmental Regulation of Development, Health, and Evolution (Second edition). Sunderland Massachusetts U.S.A.: Sinauer Associates Inc. Publishers.

Gopnik A. (2003). The theory theory as an alternative to the innateness hypothesis. W: L.M. Antony, N. Hornstein (eds.), Philosophers and Their Critics. Chomsky and His critics, 238-254. Malden, MA: Blackwell Pub. DOI: https://doi.org/10.1002/9780470690024.ch10.

Gopnik A. (2009), Rational constructivism: A new way to bridge rationalism and empiricism. Behavioral and Brain Sciences, 32(02), 208. DOI: https://doi.org/10.1017/S0140525X0900096X.

Gopnik A. (2010), Dziecko filozofem. Co dziecięce umysty mówia nam o prawdzie, miłości oraz sensie życia. Na ścieżkach umystu. Warszawa: Prószyński Media.

Gopnik A. (2011), The Theory Theory 2.0: Probabilistic models and cognitive development. Child Development Perspectives, 5(3), 161-163. DOI: https://doi.org/10.1111/j.1750-8606.2011.00179.x.

Gopnik A., Bonawitz E. (2015), Bayesian models of child development. Wiley Interdisciplinary Reviews. Cognitive Science, 6(2), 75-86. DOI: https://doi.org/10.1002/wcs.1330.

Gopnik A., Tenenbaum J.B. (2007), Bayesian networks, Bayesian learning and cognitive development. Developmental Science, 10(3), 281-287. DOI: https://doi.org/10.1111/j.1467-7687.2007.00584.x. 
Gopnik A., Wellman H.M. (1992), Why the child's theory of mind really is a theory. Mind \& Language, 7(1-2), 145-171. DOI: https://doi.org/10.1111/j.1468-0017.1992.tb00202.x.

Gopnik A., Wellman H.M. (2012), Reconstructing constructivism: causal models, Bayesian learning mechanisms, and the theory theory. Psychological Bulletin, 138(6), 1085-1108. DOI: https://doi.org/10.1037/a0028044.

Gopnik A., Meltzoff A.N., Kuhl P.K. (1999), The Scientist in the Crib: What Early Learning Tells us about the Mind. Pymble, NSW, New York: HarperCollins e-books.

Gould S.J., Lewontin R.C. (1979), The spandrels of san marco and the panglossian paradigm: a critique of the adaptationist programme. Proceedings of the Royal Society B: Biological Sciences, 205(1161), 581-598. DOI: https://doi.org/10.1098/rspb.1979.0086.

Gould S.J., Vrba E.S. (1982), Exaptation - a missing term in the science of form. Paleobiology, 8(01), 4-15. DOI: https://doi.org/10.1017/S0094837300004310.

Helming K.A., Strickland B., Jacob P. (2016), Solving the puzzle about early belief-ascription. Mind \& Language, 31(4), 438-469. DOI: https://doi.org/10.1111/mila.12114.

Kirchhoff M.D., Froese T. (2017), Where there is life there is mind: in support of a strong life-mind continuity thesis. Entropy, 19(4), 169. DOI: https://doi.org/10.3390/e19040169.

Kovács Á.M., Téglás E., Endress A.D. (2010), The social sense: Susceptibility to others' beliefs in human infants and adults. Science (New York, N.Y.), 330(6012), 1830-1834. DOI: https://doi.org/10.1126/science.1190792.

Kristen S., Sodian B. (2014), Theory of mind (tom) in early education: developmental progression of early theory of mind skills, social developmental factors and the importance of tom for learning. W: O.N. Saracho (ed.), Contemporary Perspectives in Early Childhood Education. Contemporary Perspectives on Research in Theory of Mind in Early Childhood Education, 291-320. Charlotte, North Carolina: Information Age Publishing.

Leslie A.M., Friedman O., German T.P. (2004), Core mechanisms in "theory of mind". Trends in Cognitive Sciences, 8(12), 528-533. DOI: https://doi.org/10.1016/j.tics.2004.10.001.

Lewis C., Carpendale J.I.M., Stack J. (2013), Anticipation and social interaction: Commentary on "Stepping off the pendulum: Why only an action-based approach can transcend the nativist-empiricist debate" by J. Allen and M. Bickhard. Cognitive Development, 28(2), 159-163. DOI: https://doi.org/10.1016/j. cogdev.2013.01.008.

Lewkowicz D.J. (2011), The biological implausibility of the nature-nurture dichotomy \& what it means for the study of infancy. Infancy: The Official Journal of the International Society on Infant Studies, 16(4), 331-367. DOI: https://doi.org/10.1111/j.1532-7078.2011.00079.x.

Lewontin R.C. (2001), The Triple Helix: Gene, Organism and Environment. Cambridge (Massachusetts), London: Harvard University Press.

Lightfoot D. (1989), The child's trigger experience: Degree-0 learnability. Behavioral and Brain Sciences, 12(02), 321. DOI: https://doi.org/10.1017/S0140525X00048883.

Low J., Apperly I.A., Butterfill S.A., Rakoczy H. (2016), Cognitive architecture of belief reasoning in children and adults: a primer on the two-systems account. Child Development Perspectives, 10(3), 184-189. DOI: https://doi.org/10.1111/cdep.12183.

Mameli M., Bateson P. (2011), An evaluation of the concept of innateness. Philosophical Transactions of the Royal Society of London. Series B, Biological Sciences, 366(1563), 436-443. DOI: https://doi.org/10.1098/ rstb.2010.0174.

Mayer A., Träuble B. (2012), Synchrony in the onset of mental state understanding across cultures?: A study among children in Samoa. International Journal of Behavioral Development, 37(1), 21-28. DOI: https:// doi.org/10.1177/0165025412454030.

Meristo M., Morgan G., Geraci A., Iozzi L., Hjelmquist E., Surian L., Siegal M. (2012), Belief attribution in deaf and hearing infants. Developmental Science, 15(5), 633-640. DOI: https://doi.org/10.1111/j.14677687.2012.01155.x.

Meristo M., Strid K., Hjelmquist E. (2016), Early conversational environment enables spontaneous belief attribution in deaf children. Cognition, 157, 139-145. DOI: https://doi.org/10.1016/j.cognition.2016.08.023.

Milligan K., Astington J.W., La Dack (2007), Language and theory of mind: meta-analysis of the relation between language ability and false-belief understanding. Child Development, 78(2), 622-646. DOI: https:// doi.org/10.1111/j.1467-8624.2007.01018.x. 
Mills S. (2001), The idea of different folk psychologies. International Journal of Philosophical Studies, 9(4), 501-519. DOI: https://doi.org/10.1080/09672550110081285.

Moczek A. (2014), Towards a theory of development through a theory of developmental evolution. W: A. Minelli, T. Pradeu (eds.), Towards a Theory of Development, 218-226. Oxford: Oxford University Press. Nelson K. (2005), Language pathways into the community of minds. W: J.W. Astington, J.A. Baird (eds.), Why Language Matters for Theory of Mind, 26-49. New York, Oxford: Oxford University Press.

Nęcka E., Orzechowski J., Szymura B. (2006), Psychologia poznawcza. Warszawa: Wydawnictwo Naukowe PWN; Academica Wydawnictwo SWPS.

Onishi K.H., Baillargeon R. (2005), Do 15-month-old infants understand false beliefs? Science (New York, N.Y.), 308(5719), 255-258. DOI: https://doi.org/10.1126/science.1107621.

Oyama S. (1985/2000), The Ontogeny of Information. Duke University Press.

Perner J., Ruffman T. (2005), Psychology. Infants' insight into the mind: how deep? Science (New York, N.Y.), 308(5719), 214-216. DOI: https://doi.org/10.1126/science.1111656.

Pezzulo G., Vosgerau G., Frith U., Hamilton A.F. d. C., Heyes C., Iriki A., Tramacere A. (2015), Acting up: an approach to the study of cognitive development. W: A.K. Engel, K.J. Friston, D. Kragic (eds.), Strüngmann Forum Reports. The Pragmatic Turn. Toward Action-oriented Views in Cognitive Science 49-77. Cambridge, MA: The MIT Press.

Piattelli-Palmarini M. (ed.). (1980), Language and Learning: The Debate between Jean Piaget and Noam Chomsky. Cambridge, MA: Harvard University Press.

Pigliucci M., Müller G.B. (ed.). (2010), Evolution - the Extended Synthesis. Cambridge, MA: The MIT Press.

Pinker S. (2014/1994), The Language Instinct: How the Mind Creates Language. Brilliance Audio.

Poulin-Dubois D., Chow V. (2009), The effect of a looker's past reliability on infants' reasoning about beliefs. Developmental Psychology, 45(6), 1576-1582. DOI: https://doi.org/10.1037/a0016715.

Racine T.P. (2013), How useful are the concepts "innate" and "adaptation" for explaining human development. Human Development, 56(3), 141-146. DOI: https://doi.org/10.1159/000350925.

Ruffman T., Taumoepeau M. (2014), When and how does a theory of mind arise? W: O.N. Saracho (ed.), Contemporary Perspectives in Early Childhood Education. Contemporary Perspectives on Research in Theory of Mind in Early Childhood Education 45-63. Charlotte, NC: Information Age Publishing.

Ruffman T., Slade L., Rowlandson K., Rumsey C., Garnham A. (2003), How language relates to belief, desire, and emotion understanding. Cognitive Development, 18(2), 139-158. DOI: https://doi.org/10.1016/ S0885-2014(03)00002-9.

Samuels R. (2002). Nativism in cognitive science. Mind \& Language, 17(3), 233-265. DOI: https://doi. org/10.1111/1468-0017.00197.

Samuels R. (2004). Innateness in cognitive science. Trends in Cognitive Sciences, 8(3), 136-141. DOI: https:// doi.org/10.1016/j.tics.2004.01.010.

Scholl B.J., Leslie A.M. (2001), Minds, modules, and meta-analysis. Child Development, 72(3), 696-701. DOI: https://doi.org/10.1111/1467-8624.00308.

Scott R.M., Baillargeon R. (2009), Which penguin is this? Attributing false beliefs about object identity at 18 months. Child Development, 80(4), 1172-1196. DOI: https://doi.org/10.1111/j.1467-8624.2009.01324.x.

Scott R.M., Baillargeon R. (2017), Early false-belief understanding. Trends in Cognitive Sciences, 21(4), 237-249. DOI: https://doi.org/10.1016/j.tics.2017.01.012.

Scott R.M., Baillargeon R., Song H.-j., Leslie A.M. (2010), Attributing false beliefs about non-obvious properties at 18 months. Cognitive Psychology, 61(4), 366-395. DOI: https://doi.org/10.1016/j.cogpsych.2010.09.001.

Spencer J.P., Blumberg M.S., McMurray B., Robinson S.R., Samuelson L.K., Tomblin J.B. (2009), Short arms and talking eggs: Why we should no longer abide the nativist-empiricist debate. Child Development Perspectives, 3(2), 79-87. DOI: https://doi.org/10.1111/j.1750-8606.2009.00081.x.

Strijbos D.W., De Bruin L.C. (2013), Universal belief-desire psychology?: A dilemma for theory theory and simulation theory. Philosophical Psychology, 26(5), 744-764. DOI: https://doi.org/10.1080/09515089.2012.711034.

Träuble B., Marinović V., Pauen S. (2010), Early theory of mind competencies: do infants understand others' beliefs? Infancy, 15(4), 434-444. DOI: https://doi.org/10.1111/j.1532-7078.2009.00025.x.

Venter C., Cohen D. (2004), The century of biology. New Perspectives Quarterly, 21(4), 73-77. DOI: https:// doi.org/10.1111/j.1540-5842.2004.00701.x. 
Villiers J.G. de, de Villiers P.A. (2014), The role of language in theory of mind development. Topics in Language Disorders, 34(4), 313-328. DOI: https://doi.org/10.1097/TLD.0000000000000037.

Vinden P.G. (1996), Junin Quechua children's understanding of mind. Child Development, 67(4), 1707-1716. DOI: https://doi.org/10.1111/j.1467-8624.1996.tb01822.x.

Wellman H.M. (2014), Making Minds: How Theory of Mind Develops. Oxford Series in Cognitive Development. Oxford, New York: Oxford University Press.

Wellman H.M., Fang F., Liu D., Zhu L., Liu G. (2006), Scaling of theory-of-mind understandings in Chinese children. Psychological Science, 17(12), 1075-1081. DOI: https://doi.org/10.1111/j.1467-9280.2006.01830.x.

Wellman H.M., Fang F., Peterson C.C. (2011), Sequential progressions in a theory-of-mind scale: Longitudinal perspectives. Child Development, 82(3), 780-792. DOI: https://doi.org/10.1111/j.1467-8624.2011.01583.x.

Westra E. (2017), Pragmatic development and the false belief task. Review of Philosophy and Psychology, 8(2), 235-257. DOI: https://doi.org/10.1007/s13164-016-0320-5.

Westra E., Carruthers P. (2017), Pragmatic development explains the Theory-of-Mind Scale. Cognition, 158, 165-176. DOI: https://doi.org/10.1016/j.cognition.2016.10.021.

Wimmer H., Perner J. (1983), Beliefs about beliefs: Representation and constraining function of wrong beliefs in young children's understanding of deception. Cognition, 13(1), 103-128. DOI: https://doi. org/10.1016/0010-0277(83)90004-5.

Wynn K. (1992), Addition and subtraction by human infants. Nature, 358(6389), 749-750. DOI: https://doi. org $/ 10.1038 / 358749 \mathrm{a} 0$.

\section{Nota autorska}

Niniejszy tekst został przygotowany w ramach projektu badawczego „O społeczno-kulturowym uwikłaniu potocznych teorii umysłu. Dyskusja o granicach uniwersalności i powszechności pojęć i atrybucji mentalnych", finansowanego przez Narodowe Centrum Nauki (grant PRELUDIUM 12, UMO-2016/23/N/HS1/02887 na lata 2017--2019).

Pragnę podziękować Arkadiuszowi Gutowi, Mateuszowi Chrólowi oraz dwóm anonimowym recenzentom za trafne uwagi, które pozwoliły na ulepszenie pierwotnej wersji tekstu. 